\begin{tabular}{|c|c|c|c|}
\hline \multirow{3}{*}{$\begin{array}{r}\text { Case Reports in } \\
\text { Gastroenterology }\end{array}$} & Case Rep Gastroenterol 2 & & \multirow[b]{2}{*}{$\begin{array}{l}\text { Karger } \\
\text { Open access }\end{array}$} \\
\hline & $\begin{array}{l}\text { DOI: } 10.1159 / 000446577 \\
\text { Publisned ontine: TVlay z6, } 2016\end{array}$ & $\begin{array}{l}\text { (c) } 2016 \text { The Author(s) } \\
\text { Published by S. Karger AG, Basel } \\
\text { www.karger.com/crg }\end{array}$ & \\
\hline & $\begin{array}{l}\text { This article is licensed under } \\
\text { International License (CC BY- }- \\
\text { Usage and distribution for comn }\end{array}$ & $\begin{array}{l}\text { mons Attribution-NonCommercial } \\
\text { ger.com/Services/OpenAccessLicense) } \\
\text { quires written permission. }\end{array}$ & \\
\hline
\end{tabular}

\title{
Pleomorphic Carcinoma of the Colon: Morphological and Immunohistochemical Findings
}

\author{
Giovanni Branca Valeria Barresi Antonio Ieni Eleonora Irato \\ Rosario Alberto Caruso \\ Department of Human Pathology 'G. Barresi', University of Messina, Messina, Italy
}

\section{Keywords}

Pleomorphic carcinoma $\cdot$ Morphology $\cdot$ Immunohistochemistry

\begin{abstract}
Pleomorphic carcinoma is an aggressive neoplasm defined by the World Health Organization (WHO) as a poorly differentiated (squamous cell carcinoma or adenocarcinoma) or undifferentiated carcinoma in which at least $10 \%$ spindle and/or giant cells are identified, or as a carcinoma constituted purely of spindle and giant cells. Although this entity has initially been shown in the lung, it has been described also in extrapulmonary locations, with only one report for a colonic site. A 65-year-old woman developed a caecal tumour. Gross examination revealed an endophytic/ulcerative mass $7 \mathrm{~cm}$ in length. Microscopically, the tumour was a poorly differentiated adenocarcinoma with a pleomorphic component that occupied more than $10 \%$ of the specimen. The tumour shared these histopathological findings with pulmonary giant cell carcinoma but differed in other clinicopathological features such as a pushing growth pattern, stage pT3N1, and an uneventful outcome 24 months after operation. The pleomorphic component showed morphological and immunohistochemical features compatible with mitotic catastrophe, a non-apoptotic cell death occurring in cycling cells after aberrant mitosis. These features included multinucleation, micronucleation, atypical mitoses, foci of geographic necrosis, as well as immunohistochemical overexpression of p53 and Ki-67. The interpretation of the pleomorphic component as morphological expression of mitotic catastrophe may be useful in comprehending the pathogenesis of this rare neoplasm, and it may have practical implications as a potential cancer therapeutic target.
\end{abstract}

(C) 2016 The Author(s)

Published by S. Karger AG, Basel

KARGER
Dr. Giovanni Branca

Department of Human Pathology 'G. Barresi'

AOU Polyclinic G. Martino, Pad D

Via Consolare Valeria, IT-98125 Messina (Italy)

E-Mail giobranca81@gmail.com 


\section{Introduction}

Pleomorphic carcinoma is an aggressive tumour initially described in the lung by Nash and Stout [1]. In the 4th edition of the World Health Organization (WHO) classification of tumours of the lung, pleomorphic carcinoma is defined as a poorly differentiated (squamous cell carcinoma or adenocarcinoma) or undifferentiated carcinoma in which at least $10 \%$ spindle and/or giant cells are identified, or as a carcinoma constituted purely of spindle and giant cells [2]. Primary sites of occurrence of extrapulmonary pleomorphic carcinomas have been described in other organs such as the stomach, thyroid, gallbladder, pancreas, kidney, liver, bladder, and colon [3]. To the best of our knowledge, only one report described a case of giant cell carcinoma of the colon resembling that observed in the lung [4].

Based on the recommendations of the Nomenclature Committee on Cell Death, mitotic catastrophe is defined as a tumour-suppressive mechanism occurring during or after aberrant mitosis leading to cell death or cell senescence [5]. Histological patterns of micro- and multinucleation have been used as morphological markers for the detection of mitotic catastrophe $[5,6]$. A high frequency of multinucleated giant cells is characteristically found in pleomorphic carcinomas [3].

In this report, we present an additional case of primary pleomorphic carcinoma of the colon, and we underline similarities to and differences from pulmonary pleomorphic carcinoma. The possibility of the pleomorphic component as morphological expression of mitotic catastrophe is finally discussed.

\section{Case Report}

A 65-year-old Caucasian woman with a medical history of hypercholesterolaemia, chronic obstructive pulmonary disease, and paroxysmal tachycardia was admitted to the surgery unit of the University Hospital 'G. Martino' (Messina, Italy) in 2013 for abdominal obstructive symptoms (colicky pain to the right iliac fossa as well as borborygmi), change in bowel habits (diarrhoea), asthenia, and severe weight loss since 6 months. There was no nausea or vomiting. On physical examination, a globular and tympanic abdomen, painless at superficial and deep palpation, was evident. In addition, peristalsis was valid. She reported a history of adequate food intake with regular bowel habits, alcohol consumption $(<20 / 30 \mathrm{~g}$ daily), and smoking. There was no family history of gastrointestinal malignancy, although familiality for bladder carcinoma was reported. Abdominal ultrasonography highlighted an exophytic/stenosing mass at the level of the ascending colon. Furthermore, stool examination was positive for blood content. Afterwards, colonoscopy also revealed an exophytic/stenosing malignant neoplastic mass in the caecum, subsequently confirmed through histological evaluation of biopsy. Carcinoembryonic antigen (value for smokers $<10.0$ $\mathrm{ng} / \mathrm{ml}$ ) and carbohydrate antigen $19-9$ (value $<35 \mathrm{IU} / \mathrm{ml}$ ) were within normal limits. A contrast-enhanced computed tomography scan showed no evidence of liver or distant metastases. Furthermore, the clinical status of the patient was good. Thus, the patient underwent a surgical right hemicolectomy with lymph node dissection. The postoperative course was unremarkable and adjuvant chemotherapy was administered. There is no evidence of recurrence 24 months after tumour resection. 


\section{Materials and Methods}

Routine haematoxylin-eosin sections were made from formalin-fixed, paraffinembedded tissue. Sections were also stained with periodic acid-Schiff and Alcian blue at $\mathrm{pH}$ 2.5. Additional sections - collected on silanized, coated slides - were used for the immunohistochemical stains, using the Dako EnVision ${ }^{\mathrm{TM}}$ FLEX, High pH detection system together with Autostainer instruments. The commercial source, clone, and dilution of the primary antibodies are detailed in table 1 . The reactions were visualized by Dako EnVision ${ }^{\mathrm{TM}}$ FLEX DAB+ Chromogen. Finally, sections were counterstained with Mayer's haematoxylin. As controls, known positive tissue sections and negative controls devoid of primary antibody were used.

\section{Gross Pathology and Histopathology}

Macroscopic examination of the resected colon revealed an endophytic/ulcerative lesion measuring $7 \mathrm{~cm}$ in its greatest dimension, invading the caecum nearly to the ileocaecal valve. Microscopically, the tumour was a poorly differentiated adenocarcinoma with a grade 4 pleomorphic component that occupied up to $10 \%$ of the whole tumour section. The pleomorphic component showed trabeculae and nests of neoplastic cells possessing eosinophilic cytoplasm, as well as irregularly shaped vesicular nuclei with a single large eosinophilic nucleolus. Giant cells containing multiple nuclei, micronuclei, and prominent eosinophil nucleoli were also found (fig. 1a). The micronuclei appeared as round chromatin fragments with a diameter less than one third of the diameter of the nucleus. There were numerous atypical mitoses (fig. 1b) and large geographical necrotic areas with sharp boundaries with respect to the viable tumour tissue (fig. 1c). The tumour showed a pushing growth pattern (fig. 1d) and infiltrated the full thickness of the wall. The proximal and distal resection margins were free of tumour. Only 1 out of the 44 harvested perivisceral lymph nodes presented carcinomatous metastasis (pT3, pN1, clinical stage in accordance to the 2009 pTNM system). The histochemical stains were negative for periodic acid-Schiff and Alcian blue in all of the pleomorphic neoplastic cells. On the immunohistochemical stains, these cells were diffusely and strongly positive for CEAp, CKAE1/AE3, CK7, and vimentin, but they were negative for CK20, smooth muscle actin, desmin, synaptophysin, and $\beta$-human chorionic gonadotropin. Ki-67 immunostained more than $80 \%$ of the neoplastic cells (fig. 2b), whereas p53 labelling was shown in more than $90 \%$ of the tumoural nuclei (fig. 2 a).

\section{Discussion}

We described a rare case of pleomorphic carcinoma of the right colon showing opposing clinicopathological features. Although it was classified as a grade 4 tumour, it was characterized by a pushing growth pattern and presented only one lymph node with metastasis. These data confirm that classic grading of colorectal carcinoma is insufficient to predict a prognosis, and that further parameters such as growth patterns are needed. Accordingly, several recent studies have shown that colorectal carcinomas with pushing margins are associated with superior disease-free survival rates when compared with tumours with infiltrative margins [7]. 
The present tumour had some of the morphological features described in giant cell carcinoma of the lung, such as pleomorphic tumour cells, malignant giant cells, atypical mitoses, and coagulative necrosis. However, pleomorphic carcinoma of the lung has been reported to have a poor prognosis [2], whereas in our case, the patient has been well without evidence of recurrence or metastases 2 years after the operation. Many studies suggested that pleomorphic tumours are a heterogeneous group of neoplasms arising in different anatomical sites (e.g. lung, uterus, breast, central nervous system) characterized by variable morphological features and prognoses [8-11]. In particular, a certain percentage of patients affected by them were found to be long-term survivors despite the anaplastic morphology of their primary neoplasms $[8,10,11]$. Thus, our data reaffirm the clinicopathological heterogeneity of the pleomorphic histological type.

The differential diagnosis of pleomorphic carcinoma includes adenocarcinoma with a choriocarcinomatous component as well as mixed adenoneuroendocrine carcinoma [7, 12, 13]. A choriocarcinomatous component usually is characterized by immunoreactivity to $\beta$ human chorionic gonadotropin, which was not found in our case, while the latter was excluded by the lack of expression of neuroendocrine markers such as synaptophysin and chromogranin $[12,13]$.

In our case, multinucleated tumour cells contained not only abnormally large giant nuclei but also those that are abnormally small, in the form of micronuclei. The presence of micronuclei is usually overlooked in the reports of pleomorphic carcinoma in the current literature. Micronuclei derive from chromosomes and/or chromosome fragments that have been irregularly distributed between daughter nuclei after abnormal mitosis [5]. Besides micronucleation and multinucleation, our case was characterized by multipolar mitoses and tissue necrosis. We interpret these findings as a morphological expression of mitotic catastrophe, a particular type of cell death occurring in tumour cells after aberrant mitosis $[5,6$, 14]. After mitotic catastrophe, tumour cells may continue to divide and thus develop polyploidy and/or aneuploidy [15].

Ki-67 is an antigen of cell proliferation frequently used in routine histopathological diagnostics as a prognostic factor in more malignancies [16]. Specifically, it is an epitope of a nuclear and nucleolar protein of $360 \mathrm{kDa}$ only expressed in nuclei of cells in active proliferation, i.e. during cell cycle phases $\mathrm{G}_{1}, \mathrm{~S}, \mathrm{G}_{2}$, and $\mathrm{M}$, but not in the quiescent phase, i.e. in cell cycle phase $\mathrm{G}_{0}[17,18]$. Normally, p53 acts as a guardian of the genome, protecting cells against cancer via two main ways: by determining cell cycle arrest at $\mathrm{G}_{1}$ and $\mathrm{G}_{2} / \mathrm{M}$ and by inducing cellular apoptosis $[19,20]$. p53 mutation predisposes to mitotic catastrophe $[14$, $15,18]$. Nuclear p53 immunohistochemical positivity in tumour cells suggests mutation in the p53 gene $[21,22]$. Thus, immunohistochemical overexpression of p53 and Ki- 67 constitutes further evidence of mitotic catastrophe in the pleomorphic component of our case of colonic neoplasm.

Ionizing radiation and different classes of cytotoxic agents induce cell death through mitotic catastrophe $[15,18]$. Histological recognition of mitotic catastrophe could be useful to predict an eventual pharmacological modulation (induction or inhibition) of tumour cell death [15]. Therefore, mitotic catastrophe has recently gained attention as a potential therapeutic target in neoplasms [23-25].

In summary, we reported a case of colorectal carcinoma with clinicopathological features partially similar to pleomorphic cell carcinoma of the lung, a neoplasm associated with a bad prognosis. In particular, this tumour presented only one lymph node with metastasis, and the patient is still well 2 years after the operation. This case presented morphological and immunohistochemical features compatible with mitotic catastrophe, a form of non- 


\begin{tabular}{l|l}
\hline $10.1159 / 000446577$ & $\begin{array}{l}\text { C } 2016 \text { The Author(s). Published by S. Karger AG, Basel } \\
\text { www.karger.com/crg }\end{array}$ \\
\hline $\begin{array}{l}\text { Branca et al.: Pleomorphic Carcinoma of the Colon: Morphological and } \\
\text { Immunohistochemical Findings }\end{array}$
\end{tabular}

apoptotic cell death due to aberrant mitosis. The inclusion of mitotic catastrophe as part of a microscopic evaluation may be useful for understanding the pathogenesis of this rare entity and for new cancer treatment modalities.

\section{Statement of Ethics}

All relevant ethical issues were identified and discussed with the local ethics committee. No further ethical approval was necessary to perform histology and immunohistochemistry in the case included in this report.

\section{Disclosure Statement}

The authors have nothing to disclose.

\section{References}

1 Nash AD, Stout AP: Giant carcinoma of the lung: report of 5 cases. Cancer 1958;11:369-376.

2 Kerr KM, Pelosi G, Austin JHM, Brambilla E, Geisinger K, Jambhekar NA, Jett J, Koss MN, Nicholson AG, Powell CA, Riely G, Rossi G, Travis WD, Tsuta K, van Schil P, Yang P: Pleomorphic, spindle cell, and giant cell carcinoma; in Travis WD, Brambilla E, Burke AP, Marx A, Nicholson AG (eds): WHO Classification of Tumours of the Lung, Pleura, Thymus and Heart. Lyon, IARC, 2015, pp 88-90.

3 Al-Nafussi AI: Common histological pattern and cell types of tumors: distinctive cell type; in Al-Nafussi AI (ed): Tumor Diagnosis: Practical Approach and Pattern Analysis. London, Hodder Arnold, 2005, p 52.

4 Tajima S, Waki M, Tsuchiya T, Hoshi S: Granulocyte colony-stimulating factor-producing undifferentiated carcinoma of the colon mimicking a pulmonary giant cell carcinoma: a case showing overexpression of CD44 along with highly proliferating nestin-positive tumor vessels. Int J Clin Exp Pathol 2014;7:7034-7041.

-5 Kroemer G, Galluzzi L, Vandenabeele P, Abrams J, Alnemri ES, Baehrecke EH, Blagosklonny MV, El-Deiry WS, Golstein P, Green DR, Hengartner M, Knight RA, Kumar S, Lipton SA, Malorni W, Nuñez G, Peter ME, Tschopp J, Yuan J, Piacentini M, Zhivotovsky B, Melino G: Classification of cell death: recommendations of the Nomenclature Committee on Cell Death 2009. Cell Death Differ 2009;16:3-11.

-6 Galluzzi L, Vitale I, Abrams JM, Alnemri ES, Baehrecke EH, Blagosklonny MV, Dawson TM, Dawson VL, El-Deiry WS, Fulda S, Gottlieb E, Green DR, Hengartner MO, Kepp O, Knight RA, Kumar S, Lipton SA, Lu X, Madeo F, Malorni W, Mehlen P, Nuñez G, Peter ME, Piacentini M, Rubinsztein DC, Shi Y, Simon HU, Vandenabeele P, White E, Yuan J, Zhivotovsky B, Melino G, Kroemer G: Molecular definitions of cell death subroutines: recommendations of the Nomenclature Committee on Cell Death 2012. Cell Death Differ 2012;19:107-120.

7 Hamilton SR, Bosman FT, Boffetta P, Llyas M, Morreau H, Nakamura SL, Quirke P, Riboli E, Sobin LH: Carcinoma of the colon and rectum; in Bosman FT, Carneiro F, Hruban RH, Theise ND (eds): WHO Classification of Tumours of the Digestive System. Lyon, IARC, 2010, pp 134-146.

-8 Attanoos RL, Papagiannis A, Suttinont P, Goddard H, Papotti M, Gibbs AR: Pulmonary giant cell carcinoma: pathological entity or morphological phenotype? Histopathology 1998;32:225-231.

-9 Silver SA, Tavassoli FA: Pleomorphic carcinoma of the breast: clinico-pathological analysis of 26 cases of an unusual high-grade phenotype of ductal carcinoma. Histopathology 2000;36:505-514.

10 Mulligan AM, Plotkin A, Rouzbahman M, Soslow RA, Gilks B, Clarke BA: Endometrial giant cell carcinoma: a case series and review of the spectrum of endometrial neoplasms containing giant cells. Am J Surg Pathol 2010;34:1132-1138.

11 Ida CM, Rodriguez FJ, Burger PC, Caron AA, Jenkins SM, Spears GM, Aranguren DL, Lachance DH, Giannini C: Pleomorphic xanthoastrocytoma: natural history and long-term follow-up. Brain Pathol 2015;25:575-586.

12 Klimstra DS, Arnold R, Capella C, Klöppel G, Komminoth P, Solcia E, Rindi G: Neuroendocrine neoplasms of the colon and rectum; in Bosman FT, Carneiro F, Hruban RH, Theise ND (eds): WHO Classification of Tumours of the Digestive System. Lyon, IARC, 2010, pp 174-177. 


\begin{tabular}{l}
\hline $\begin{array}{l}\text { 10.1159/000446577 } \\
\text { (C) } 2016 \text { The Author(s). Published by S. Karger AG, Basel } \\
\text { www.karger.com/crg }\end{array}$ \\
\hline $\begin{array}{l}\text { Branca et al.: Pleomorphic Carcinoma of the Colon: Morphological and } \\
\text { Immunohistochemical Findings }\end{array}$
\end{tabular}

13 Jiang L, Wu JT, Peng X: Primary choriocarcinoma of the colon: a case report and review of the literature. World J Surg Oncol 2013;11:23.

14 Galluzzi L, Maiuri MC, Vitale I, Zischka H, Castedo M, Zitvogel L, Kroemer G: Cell death modalities: classification and pathophysiological implications. Cell Death Differ 2007;14:1237-4123.

15 Vakifahmetoglu H, Olsson M, Zhivotovsky B: Death through a tragedy: mitotic catastrophe. Cell Death Differ 2008;15:1153-1162.

16 Yerushalmi R, Woods R, Ravdin PM, Hayes MM, Gelmon KA: Ki67 in breast cancer: prognostic and predictive potential. Lancet Oncol 2010;11:174-183.

-17 Caruso RA, Fedele F, Consolo P, Luigiano C, Venuti A, Cavallari V: Abnormal nuclear structures (micronuclei, nucleoplasmic bridges, and nuclear buds) in a pleomorphic giant cell carcinoma of the stomach. Ultrastruct Pathol 2008;32:11-15.

18 Caruso R, Fedele F, Lucianò R, Branca G, Parisi C, Paparo D, Parisi A: Mitotic catastrophe in malignant epithelial tumors: the pathologist's viewpoint. Ultrastruct Pathol 2011;35:66-71.

19 Levine AJ, Moshe 0: The first 30 years of p53: growing ever more complex. Nat Rev Cancer 2009;9:749758.

20 Kroemer G, Bravo-San Pedro JM, Galluzzi L: Novel function of cytoplasmic p53 at the interface between mitochondria and the endoplasmic reticulum. Cell Death Dis 2015;6:e1698.

21 Galluzzi L, Kepp 0, Kroemer G: TP53 and MTOR crosstalk to regulate cellular senescence. Aging (Albany NY) 2010;2:535-537.

Levine AJ, Momand J, Finlay CA: The p53 tumour suppressor gene. Nature 1991;351:453-456. mitotic catastrophe in tumour cells. Drug Resist Updat 2001;4:303-313.

24 Morelli MB, Amantini C, Santoni M, Soriani A, Nabissi M, Cardinali C, Santoni A, Santoni G: Axitinib induces DNA damage response leading to senescence, mitotic catastrophe, and increased NK cell recognition in human renal carcinoma cells. Oncotarget 2015;6:36245-36259.

25 Mak JP, Man WY, Chow JP, Ma HT, Poon RY: Pharmacological inactivation of CHK1 and WEE1 induces mitotic catastrophe in nasopharyngeal carcinoma cells. Oncotarget 2015;6:21074-21084. 


\begin{tabular}{ll|l} 
Case Reports in & $\begin{array}{l}\text { Case Rep Gastroenterol 2016;10:233-240 } \\
\text { Gastroenterology }\end{array}$ & $\begin{array}{l}\text { @ 2016 The Author(s). Published by S. Karger AG, Basel } \\
\text { www.karger.com/crg }\end{array}$ \\
$\begin{array}{l}\text { Branca et al.: Pleomorphic Carcinoma of the Colon: Morphological and } \\
\text { Immunohistochemical Findings }\end{array}$
\end{tabular}
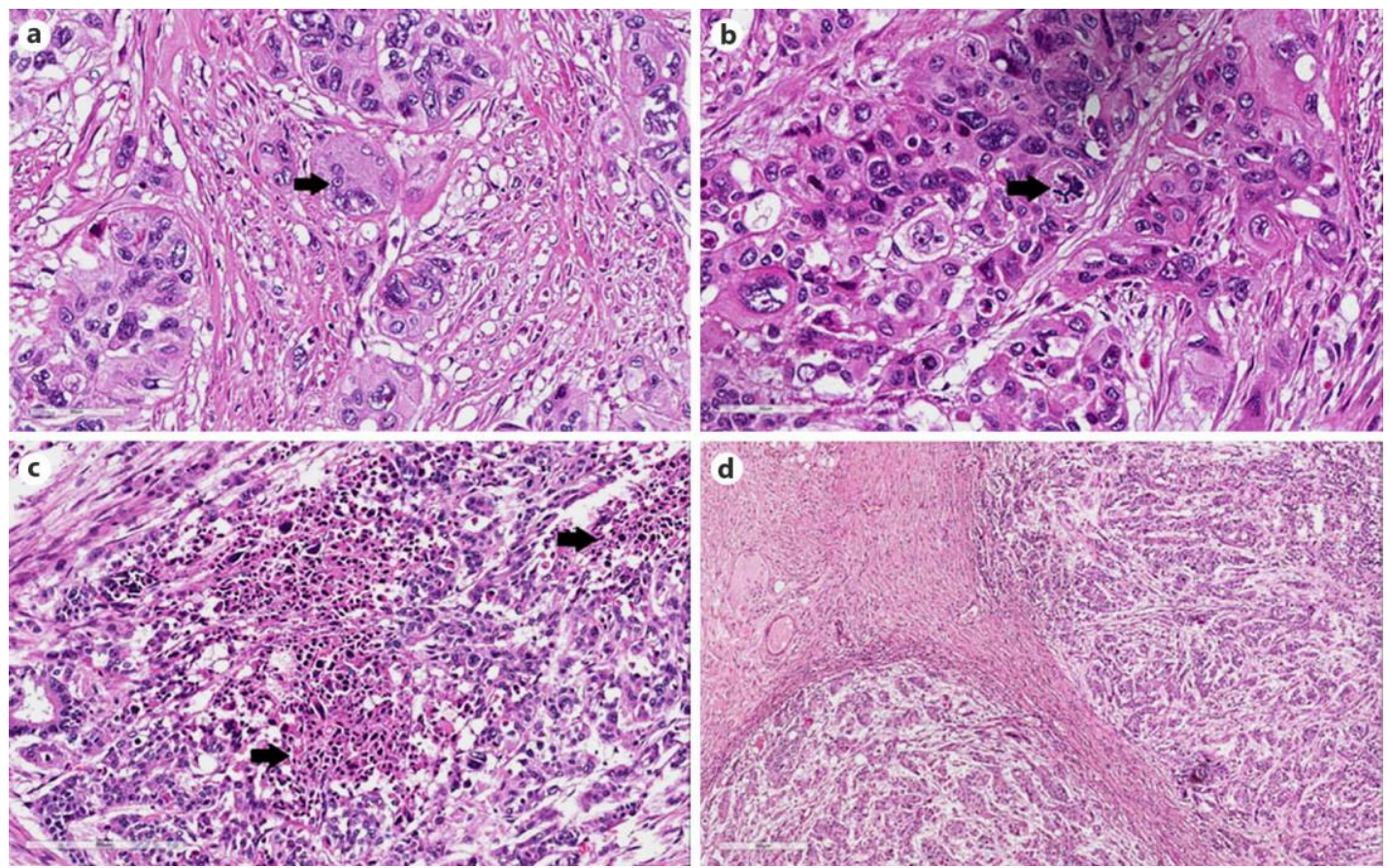

Fig. 1. Histological findings. a Giant pleomorphic cell with micronuclei (arrow). HE. $\times 400$. b High-power view of atypical mitosis (arrow). HE. $\times 400$. c Low-power view of geographical necrotic areas (arrows) surrounded by viable pleomorphic cancer cells. HE. $\times 100$. $d$ Pushing-type neoplastic infiltrative margins. HE. $\times 40$. 


\begin{tabular}{|c|c|c|}
\hline \multirow{3}{*}{$\begin{array}{r}\text { Case Reports in } \\
\text { Gastroenterology }\end{array}$} & \multirow{2}{*}{\multicolumn{2}{|c|}{ Case Rep Gastroenterol 2016;10:233-240 }} \\
\hline & & \\
\hline & $10.1159 / 000446577$ & $\begin{array}{l}\text { (c) } 2016 \text { The Author(s). Published by S. Karger AG, Basel } \\
\text { www.karger.com/crg }\end{array}$ \\
\hline & $\begin{array}{l}\text { Branca et al.: Pleomorphic } \\
\text { Immunohistochemical Findings }\end{array}$ & Carcinoma of the Colon: Morphological and \\
\hline
\end{tabular}

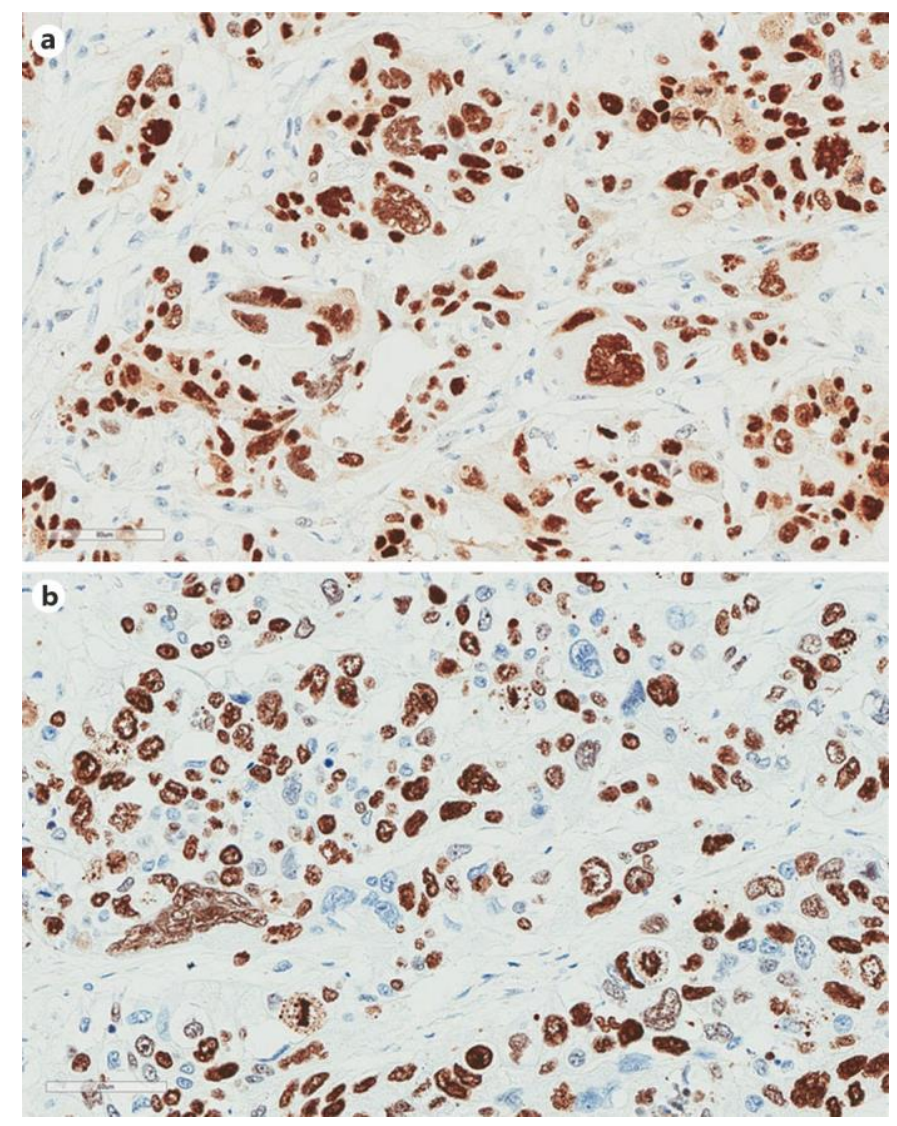

Fig. 2. Immunohistochemical characteristics. a p53 immunoreactivity in pleomorphic nuclei. Mayer's haemalum counterstain. $\times 200$. b Giant pleomorphic nuclei and atypical mitosis decorated by Mib-1 immunostaining. Mayer's haemalum counterstain. $\times 200$.

Table 1. Antibodies used in this study

\begin{tabular}{llll}
\hline Antigen & Clone & Dilution & Source \\
\hline Ki-67 & MIB-1 & $1: 150$ & DakoCytomation, Copenhaghen, Denmark \\
Vimentin & V9 & $1: 1,000$ & DakoCytomation, Copenhaghen, Denmark \\
p53 & D0-7 & $1: 200$ & DakoCytomation, Copenhaghen, Denmark \\
Pancytokeratin & AE1/AE3 & $1: 50$ & DakoCytomation, Copenhaghen, Denmark \\
Cytokeratin 7 & OV-TL 12/30 & $1: 150$ & DakoCytomation, Copenhaghen, Denmark \\
Cytokeratin 20 & Ks 20.8 & $1: 100$ & DakoCytomation, Copenhaghen, Denmark \\
Desmin & D33 & $1: 50$ & DakoCytomation, Copenhaghen, Denmark \\
Smooth muscle actin & A A4 & $1: 200$ & DakoCytomation, Copenhaghen, Denmark \\
Synaptophysin & DAK-SYNAP & $1: 50$ & DakoCytomation, Copenhaghen, Denmark \\
$\beta$-Human chorionic gonadotropin & polyclonal & $1: 10,000$ & DakoCytomation, Copenhaghen, Denmark \\
CEAp & polyclonal & $1: 2,000$ & DakoCytomation, Copenhaghen, Denmark \\
\hline
\end{tabular}

